\title{
LIQUIDITY TRAP IN THE UNITED STATES, THE EURO AREA AND JAPAN
}

When a country falls into a liquidity trap it means that its central bank lacks an effective expansionary monetary policy aimed at increasing consumption and investment demand. Market participants (households and enterprises), instead of increasing demand, accumulate a growing money supply in the form of cash. Keynes argued that for an economy in a liquidity trap, the only way to increase demand in the country and to stimulate the economy is to conduct expansionary fiscal policy by increasing government spending or reducing taxes.

The aim of the research is to verify the empirical hypothesis of the liquidity trap in three of the largest economies in the world, formerly known as the Global Triad (i.e. the USA, the euro zone and Japan), after the 2008 financial crisis. Research methods based on literature studies in macroeconomics and finance, as well as statistical methods, were used in the study. All statistical data came from the statistical office of the European Union - EUROSTAT, and from the statistical database of the United Nations Conference on Trade and Development - UNCTADstat.

Keywords: liquidity trap, financial crisis, monetary policy

JEL Codes: E52, E62, P24

\section{Introduction}

Comparing the evolution of real GDP per capita in the United States, the euro area and Japan since 2008, it can be seen that development-oriented activities in the USA were much more effective in stimulating economic recovery than in other studied economies. However, the initial response of the European Central Bank (ECB) and the Federal Reserve System (FED) in terms of monetary policy was quite similar. Monetary expansion brought interest rates in the above-mentioned economies to zero at the beginning of 2009.

The initial idea was quite simple. By increasing the nominal money supply, market participants with financial surpluses were to be encouraged to buy government bonds. The growing demand for bonds was to cause an increase in bond prices, and thus a decrease in their profitability, stimulating consumption and investment through the socalled Keynes effect. However, with interest rates close to zero in the US, euro zone and Japanese economies, they faced "liquidity traps", discouraging market participants from buying bonds.

Hence, the goal of the research is to verify the empirical hypothesis of the liquidity trap in three of the largest economies in the world, i.e. in the US, the euro area and Japan after the 2008 financial crisis. In the paper utilizes research methods based on literature studies in macroeconomics and finance as well as statistical methods. All statistical data used in the work came from the statistical office of the European Union - EUROSTAT 
and from the statistical database of the United Nations Conference on Trade and Development - UNCTADstat.

\section{The essence and causes of the liquidity trap}

In economic literature, there are at least four different definitions of the liquidity trap formulated by well-known world economists. According to Eccles, the liquidity trap is a situation in which expansive, open markets contribute to the accumulation of surplus financial reserves in commercial banks. The surplus of financial reserves may result from the fact that even at a low interest rate, when the economic development outlook is pessimistic, enterprises may not be interested in further expansion at a given moment, and commercial banks may not be interested in incurring greater risk associated with granting loans. ${ }^{1}$

In turn, according to Keynes, the liquidity trap is a situation where investors are ready, with very little price incentive, to replace long-term bonds with cash. The reason for such a situation is that market participants believe that bond prices have reached their peak. In other words, there is a perception that long-term interest rates have already reached their minimums. ${ }^{2}$

However, the liquidity trap according to the concept of Hicks is based on his IS-LM model. In his view, at low interest rates, money demand can be perfectly flexible, and money and long-term bonds are ideal substitutes. The Hicks liquidity trap means that if central monetary authorities attempted to raise the interest rate by selling bonds in an open market, such actions would fail. Savings holders would reduce their cash resources with a small price incentive. ${ }^{3}$

Finally, the concept of the liquidity trap according to Krugman is identical to the concept of the liquidity trap of Hicks, except that in the first case the short-term interest rate is taken into account, not the long-term interest rate. If it is assumed that the term structure of interest rates is exogenous, then the concepts of Krugman and Hicks are the same. ${ }^{4}$

\section{The liquidity trap in light of the results of selected empirical analyses}

Extensive liquidity trap research has been conducted in recent years to verify theoretical analysis with business practice. Tobin proved that there is a liquidity trap because the demand curve for so-called "free money" increases as interest rates fall, but only to a certain level. However, Tobin's research results did not allow an unequivocal statement of the liquidity trap in practice. The main limitation in Tobin's study was that he did not consider the impact of total wealth on society's liquidity preferences. ${ }^{5}$

${ }^{1}$ T. G. Moe, S. Marriner: Eccles and the 1951 Treasury - Federal Reserve Accord: Lessons for Central Bank Independence, Levy Economics Institute of Bard College Working Paper, No. 747/2013, p. 1-349.

${ }^{2}$ J. M. Keynes: The General Theory of Employment, Interest, and Money, Macmillan, London 1936.

${ }^{3}$ J. R.Hicks: Mr. Keynes and the 'Classics', Econometrica, No 5(2/1937), p. 147-59.

${ }^{4}$ P.R. Krugman: It's Baaack: Japan's Slump and the Return of the Liquidity Trap, Brookings Papers on Economic Activity, No 29 (2) /1998, p. 137-206.

5 J. Tobin: Keynesian Models of Recession and Depression, American Economic Review Papers and Proceedings, No 65/1975, p. 195-202. 
In the context of standard monetary policy limited by the liquidity trap, fiscal expansion plays an important role in the economy to stimulate domestic demand. Orphanides argues that the relatively fast and large scale fiscal expansion in the United States was a key factor in determining the later revival of the economy in this country, while fiscal expansion in the euro area was much smaller and did not lead to a result of significant economic recovery in member countries. Orphanides also notes the absence of effective instruments of fiscal policy coordination among euro area member states, and that the overall fiscal policy in the euro zone only reflects the aggregation of autonomous fiscal policies of the member states in this area. ${ }^{6}$

This view seems to coincide with the views put forward by Blanchard et al., who analyzed the effects of fiscal expansion on the economies in the euro area compared to the effects of fiscal expansion in the United States. The authors assert that unlike the US, the euro zone is not a fiscal union, and that fiscal expansion can only be carried out independently by individual member states. Blanchard et al. formulate opinions that although peripheral economies in the euro area are more likely to use fiscal expansion, these opportunities are significantly limited due to existing public debt and solvency problems. Therefore, fiscal expansion has to be induced, most especially through the main euro zone economies, referred to as the so-called dominant countries (economic core countries). Nonetheless, Blanchard et al., believe that the lack of liquidity trap and higher government spending in the dominant economies have little or even negative impact on GDP in the peripheral countries. ${ }^{7}$

However, taking into account the fact that recent monetary policy in the euro area has not led to an increase in interest rates, it turns out that GDP in peripheral countries tends to increase in response to budgetary expansion in so-called economic core countries of the euro area. Under these conditions, higher public spending can increase inflation in both dominant economies and peripheral countries. Thus, this situation leads to a reduction in real interest rates. Blanchard et al. also say that an increase in government spending in dominant economies by one percent of the entire euro area's GDP has increased GDP in the peripheral countries by about one percent over the previous three years, while also causing a significant increase in prosperity across the entire euro area. ${ }^{8}$ Research reveals that the effects in the form of prosperity, however, are smaller than they could be in the context of a full fiscal union, because fiscal expansion could take place in all euro area economies, including the peripheral countries.

In turn, Thirion argues that any fiscal insurance mechanism can lead to various distortions at the level of individual member states, noting that this can be particularly severe if the fiscal insurance mechanism allows for a continuous redistribution of income between member states. In particular, he argues that, in this situation, national governments may be encouraged to avoid implementing unpopular structural reforms

\footnotetext{
${ }^{6}$ A. Orphanides: The Fiscal-Monetary Policy Mix in the Euro Area - Challenges at the Zero Lower Bound, European Commission Discussion Paper No 060/2017, p. 1-44.

${ }^{7}$ O. Blanchard, E. Cerutti, L. Summers: Inflation and Activity - Two Explorations and their Monetary Policy Implications, IMF Working Paper, No 15/2015, p. 1-28.

${ }^{8}$ O. Blanchard, E. Cerutti, L. Summers: Inflation and Activity - Two Explorations and their Monetary Policy Implications, IMF Working Paper, No 15/2015, p. 1-28.
} 
or to increase public debt, being aware of the joint and several liability of all member countries for the debts of individual economies. ${ }^{9}$

To overcome the moral hazard arising from the aforementioned specific fiscal insurance mechanism, Vandenbroucke et al. are in favor of transferring relevant fiscal competences from the national to the central level, which means a partial loss of fiscal sovereignty of the member states. Then, in the case of budget problems in a given country, there would be no consent to cut spending, e.g. on education or research and development, because such activities could worsen the long-term competitiveness of a given country. Vandenbroucke et al. argue that such a central instance should have at least the right of veto to prevent such undesirable actions at the level of individual member states. ${ }^{10}$

\section{The economic situation in the US, the euro area and Japan and the liquidity trap}

From January 2008 to December 2013, the balance of the Federal Reserve System increased by approximately USD 3.5 trillion due to the Central Bank's Large Scale Asset Purchase policy implemented to help the US economy after the financial crisis. This unconventional monetary policy, also known as Quantitative Easing, increased the availability of credit on financial markets and put pressure on lowering real interest rates. $^{11}$

In so-called normal times, i.e. in the pre-crisis period in the US, for each $1 \%$ increase in money supply, inflation increased by $0.54 \% .{ }^{12}$ In turn, in the post-financial crisis period, the money supply (M0) increased in the US by $40.29 \%$ between December 2008 and December 2013, i.e. by an average of about $8 \%$ per year. At this rate of annual increase in money supply, the annual inflation rate should increase to $4.3 \%$, which would mean an increase in the price level in the US economy of about $40 \%$ over the period 2008-2013. However, this did not happen. Despite a significant injection of $\$ 3.5$ trillion into the US economy, this did not cause a significant increase in inflation. The Federal Reserve System policy of setting positive interest rates on commercial bank reserves at the central bank only compounded the problem, making cash more attractive as a way of storing value. After a long time of zero interest rates, or super cheap credit that drives consumption and investment, the US Federal Reserve (FED) started raising interest rates in 2016 due to rising inflationary pressure. While the effective interest rate in 2016 was $0.4 \%$, it had already reached $1.7 \%$ in 2018 . This meant an increase of $325 \%$. For comparison, before the crisis in 2008 , effective interest rates increased from $1 \%$ to $5.24 \%$.

\footnotetext{
${ }^{9}$ G. Thirion: European Fiscal Union: Economic Rationale and Design Challenges. CEPS Working Document, No 01/2017,p. 1-38.

${ }^{10}$ F. Vandenbroucke, C. Luigjes, D. Wood, K. Lievens: Institutional Moral Hazard in the MultiTiered Regulation of Unemployment and Social Assistance Benefits and Activation - A Summary of Eight Country Case Studies, CEPS Special Report, No. 137/2016, p. 1-91.

11 D. K. Rosati: New trends in monetary policy after the financial crisis 2008-2012. Finance, Financial Markets, Insurance, No. 4/2016, p. 461-490.

${ }^{12}$ M. A. Arias, Y. Wen: The Liquidity Trap: An Alternative Explanation for Today's Low Inflation, The Regional Economist, 2014, April, https://www.stlouisfed.org.
} 


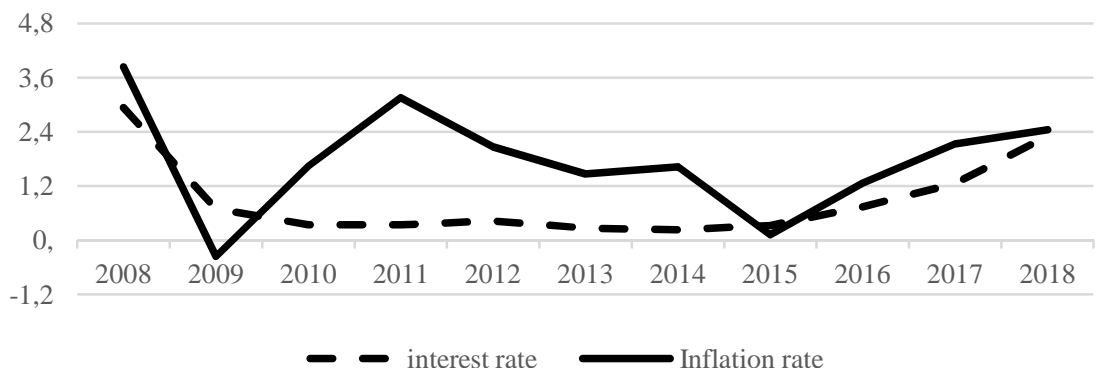

*3-month interest rate on the interbank market

Figure 1. Inflation rate and interest rate * in the USA in the period 2008-2018 [in\%]

Source: authors own study based on EUROSTAT data.

Based on the data presented in Figure 1 above, it can be seen that almost throughout the entire period (2008-2018) the real interest rate in the USA (nominal interest rate minus inflation) was negative. The exception were only the years 2009 and 2015, when the real interest rate was positive.

At the same time, it should be noted that in the period 2008-2018, despite significant fluctuations in interest rates and inflation in the US, household consumption expenditure and investment expenditure of enterprises systematically increased, except for the period 2008-2009, when a decrease in consumption and investment expenditure in the USA was recorded. At the end of 2018, consumer expenditure was higher by over $33 \%$ compared to 2008 , while investment expenditure was higher by over $27 \%$ compared to 2008. Therefore, thanks to negative real interest rates, the US economy managed to get out of the liquidity trap.

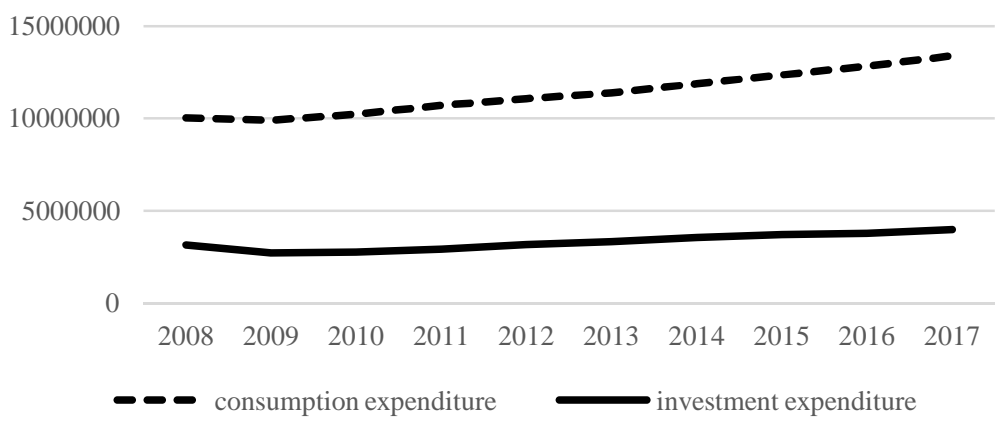

Figure 2. Consumption and investment expenditure in the USA in the period 2008-2018 [in USD million] Source: authors own study based on EUROSTAT data

It should be noted that the macroeconomic situation in the USA throughout the analyzed period was basically stable, with a simultaneous dynamic growth of public 
debt. There was a significant increase in the savings rate from $15.3 \%$ to $19.1 \%$ and an improvement in GDP growth from $-0.1 \%$ in 2008 to $3.0 \%$ at the end of 2018.

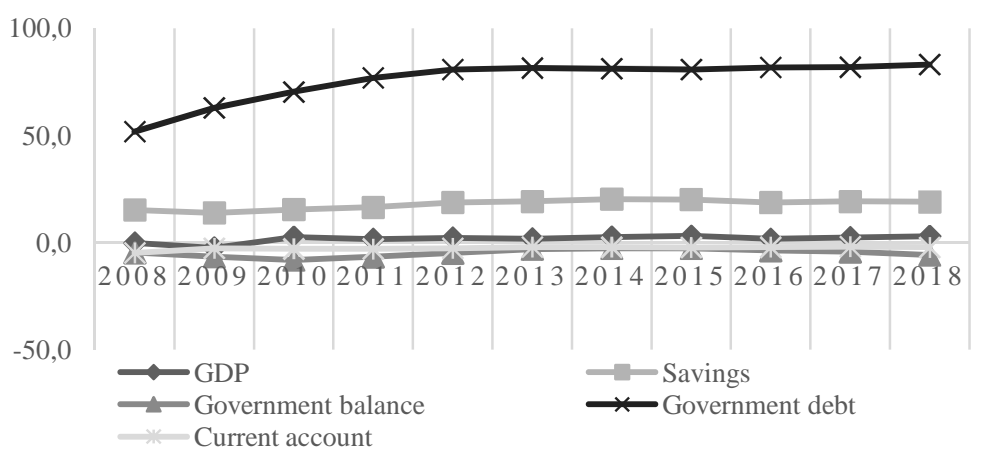

Figure 3. Macroeconomic situation in the USA in the period 2008-2018 [in \% and in relation to GDP] Source: authors own study based on UNCTADstat.

In turn, the European Central Bank for a long time refrained from following in the footsteps of the Federal Reserve System and the Central Bank of Japan (discussed later in this article). It used other instruments of non-standard monetary policy. From the end of 2008 to mid-2009 it reduced interest rates from $4.25 \%$ to 1\%, and in 2016 lowered it to the historically lowest level of zero. Moreover, the ECB deposit rate was set at a negative level, which was supposed to discourage commercial banks from keeping money in central bank accounts.

At the same time, the ECB enabled commercial banks to take cheap loans at an interest rate of $1 \%$, as part of the so-called targeted LTROs (Long Term Refinancing Operations). Commercial banks were able to use these funds to increase lending or purchase government bonds by lowering their interest rate. In addition, in May 2009, the ECB announced a program of buying mortgage-backed bonds, and in 2010 it began to gradually purchase government bonds on the secondary market under the socalled Securities Markets Program. All of the ECB's activities mentioned above led to a significant reduction in debt servicing costs.

However, the current intensity and scope of the ECB's intervention was much smaller than in the case of the Federal Reserve System and the Central Bank of Japan. In 2015, the ECB initiated the quantitative easing policy by buying commercial and government bonds, initially for EUR 60 billion per month, then increasing these purchases to EUR 80 billion per month. The ECB began buying bonds a few months after the Federal Reserve System completed similar operations. The ECB still keeps interest rates at a record low, while announcing the end of the bond purchase process.

In the euro area, just as in the US economy, the real interest rate was negative in the period, with the exception of the period 2008-2009, when it recorded a positive real interest rate. What's more, it can be seen that the negative real interest rate, despite the downward trend observed in the period 2012-2015, rose between 2016-2018. 


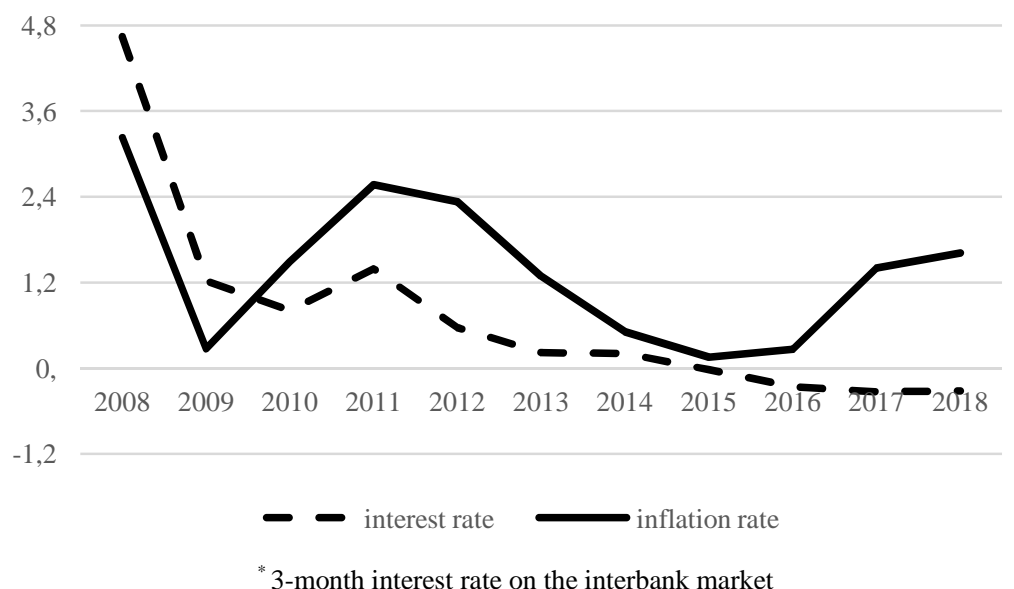

Figure 4. Inflation rate and interest rate $*$ in the euro area in the period 2008-2018 [in\%]

Source: authors own study based on EUROSTAT data.

Despite low nominal interest rates and negative real interest rates in the euro area, market participants did not significantly increase consumer and investment expenditure. Compared to 2008, household consumption expenditure decreased in 2018 by about $11 \%$, and investment expenditure of enterprises decreased by nearly $20 \%$. In this situation, the central bank does not have much opportunity to stimulate the economy, because there is no adequate response on the demand side. Thus, it can be concluded that the euro area economy is currently in a liquidity trap. What's more, if this situation lasts for a relatively long time, it may eventually lead to deflation.

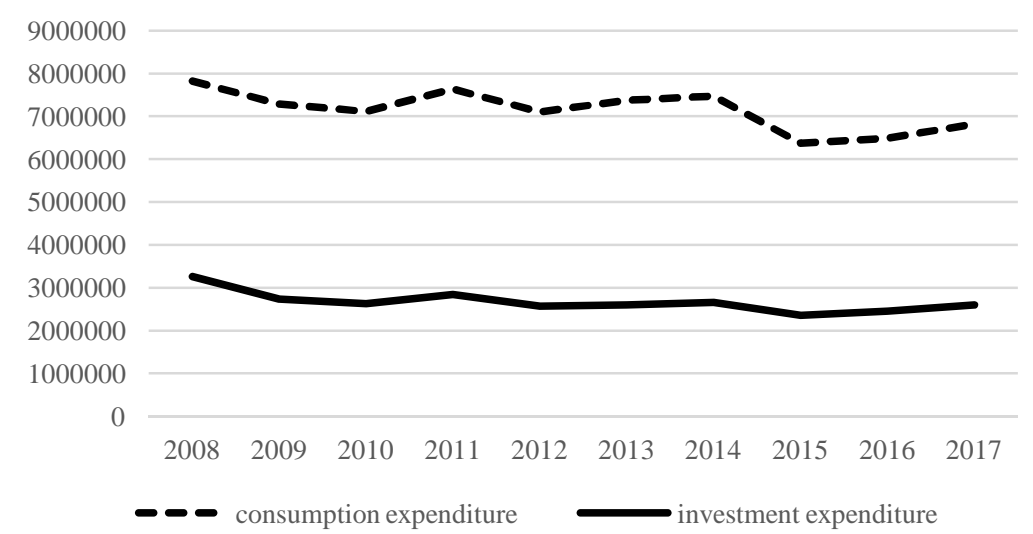

Figure 5. Consumption and investment expenditure in the euro area in the period 2008-2018 [in USD million] Source: authors own study based on EUROSTAT data.

The macroeconomic situation in the euro area throughout the analyzed period was relatively stable in relation to the main macroeconomic indicators, with a simultaneous 
dynamic growth of public debt. The savings rate increased from $21 \%$ to over $25 \%$ in 2008 -2018. At the same time, significant changes in the dynamics of GDP were noted. The lowest dynamics of $-4.5 \%$ was recorded in 2009, and the highest, $2.6 \%$, was recorded in 2017.

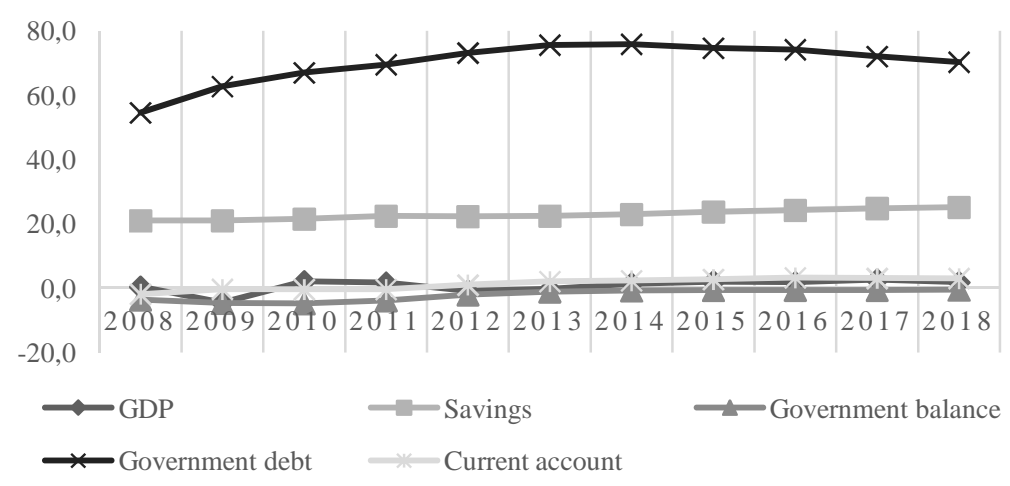

Figure 6. Macroeconomic situation in the euro area in the period 2008-2018 [in \% and in relation to GDP] Source: authors own study based on UNCTADstat.

The Japanese economy is also a good example of a country that has fallen into the liquidity trap. The increase in the monetary base of the quantitative easing policy did not transform into a corresponding increase in other monetary aggregates and did not lead to a clear increase in inflation and the expected price level. Households and enterprises are still not convinced that monetary expansion is sustainable. The real interest rate in Japan was basically positive from 2008 to 2012 due to deflation, while from 2013-2018 it was negative due to the emergence of inflation.

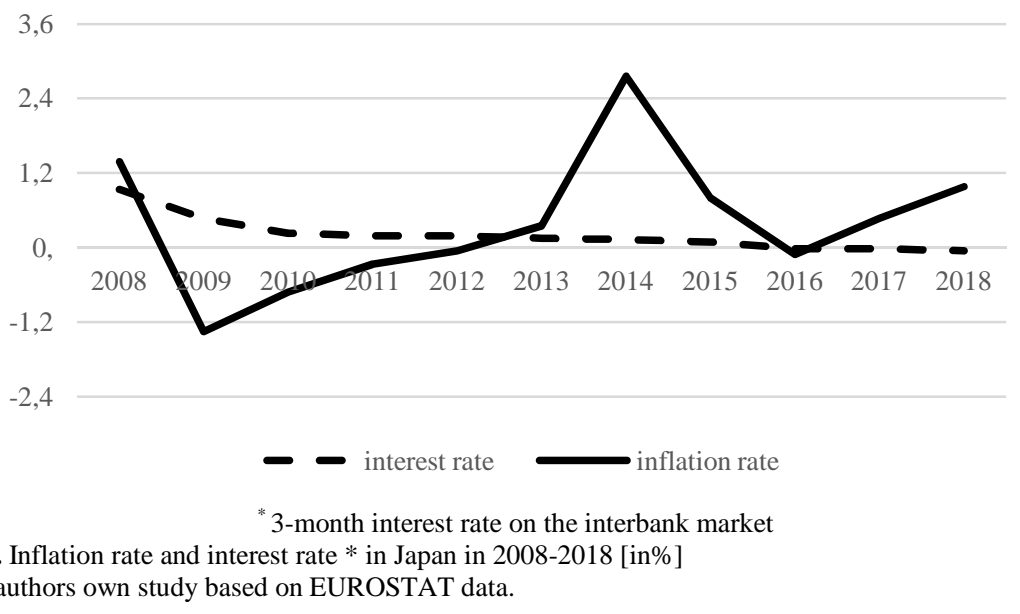

However, the expansive actions taken by the central bank and the Japanese government to increase budget spending prove ineffective to get out of the liquidity 
trap. Society expects low price growth, so there is no adequate incentive to increase consumption. Lack of sufficiently growing demand means that enterprises do not increase production and employment. Under these conditions, investments also remain stable. At the end of 2018, household consumption expenditure decreased by around $6 \%$ compared to 2008, while corporate investment expenditure dropped by more than $3 \%$.

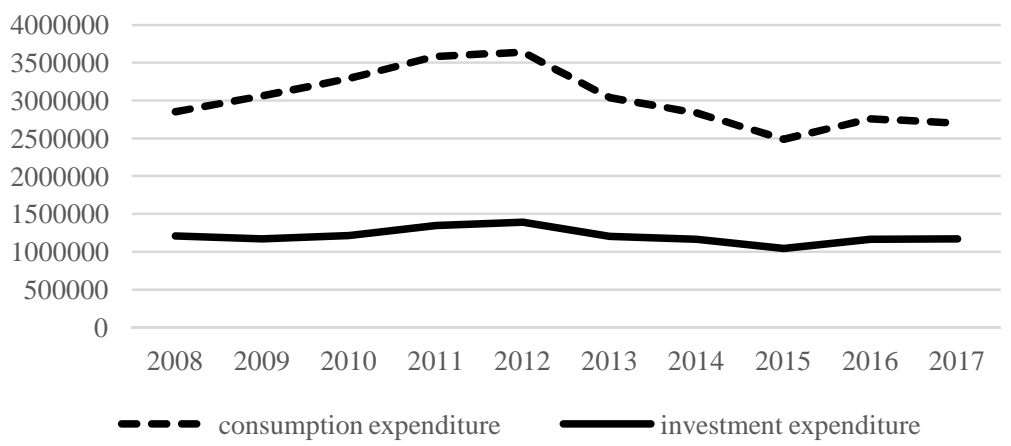

Figure 8. Consumption and investment expenditure in Japan in the period 2008-2018 [in USD million] Source: authors own study based on EUROSTAT data.

At the same time, the Japanese government introduced lifetime employment guarantees, which led to a decrease in productivity in the country. In addition, the keiretsu system gives producers a monopolistic position on the market. This reduces free market forces and innovation in the economy. Japan's population is aging, and the government has a restrictive immigration policy. Until these growth restrictions are eliminated, Japan will remain in the liquidity trap.

As a result of implemented programs to overcome the long-term stagnation in the Japanese economy, characterized by low economic growth, close to zero interest rate and even deflation, the central bank of Japan decided to significantly increase the money supply in the form of quantitative easing, and the government approved new stimulus packages and prepared a new growth strategy, including structural reforms in the field of the labor market, health care, facilitation of land turnover for investment purposes, deregulation of the service sector and changes in corporate governance. The result of these socio-economic activities was a sharp increase in public debt to the level of $153 \%$ in relation to GDP. 


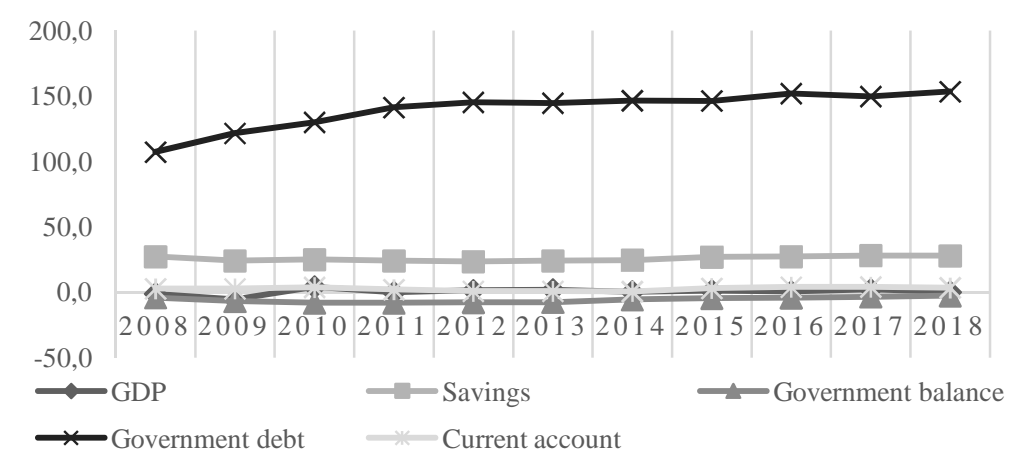

Figure 9. Macroeconomic situation in Japan in the period 2008-2018 [in \% and in relation to GDP] Source: authors own study based on UNCTADstat.

\section{Ways to get the euro area out of the liquidity trap}

According to mainstream economics, the increase in money supply causes inflation to increase, because more money falls on the same amount of available goods. However, during the liquidity trap period, the increase in the money supply is fully absorbed by excessive demand for money (liquidity). Market participants accumulate money instead of spending it, because the opportunity cost of having cash in the form of lost interest gains is zero when the nominal interest rate is zero. ${ }^{13}$

On the one hand, if the increase in money demand is proportional to the increase in money supply, inflation remains stable. On the other hand, if the demand for money increases more than proportionally to the change in money supply due to the implemented quantitative easing policy exerting downward pressure on the interest rate, the price level in the country must fall to absorb the difference between the money supply and the demand for money. Therefore, the lower the interest rate, as a result of the quantitative easing policy, the lower the price level (due to the disproportionately higher demand for money).

Not only high inflation but also low inflation can be harmful to the economy. Low inflation makes cash more attractive to investors, as a store of value. This creates the chance of falling into the liquidity trap, creating a greater limit for the central bank in terms of lowering the real interest rate in line with the expectations of market participants during the economic slowdown. In addition, quantitative easing can strengthen the liquidity trap by further lowering the long-term interest rate. In other words, more cash injections during the liquidity trap can only strengthen the liquidity trap, keeping the inflation rate low and thus a real high return on money.

An alternative to quantitative easing policy when the economy is in a liquidity trap is unconventional monetary policy in the form of so-called "helicopter money". ${ }^{14}$ Although the original concept of "helicopter money" describes central banks making payments directly to individuals, economists use the term "helicopter money"

\footnotetext{
${ }^{13}$ https://www.ecb.europa.eu

${ }^{14}$ M. Friedman: The Role of Monetary Policy. American Economic Review, No 58(1/1968), p. 1-17.
} 
to refer to a wide range of different political ideas, including constant monetization of the budget deficit with the added element of attempting to change the inflation expectations of market participants. This concept has been referred to as the "civic dividend". ${ }^{15}$

In general, expansionary monetary policy, including quantitative easing policy and the concept of "helicopter money", involves the creation of money by the central bank to increase the money supply. However, the impact of the quantitative easing policy on the central bank's balance sheet is quite different than in the case of the concept of "helicopter money". As part of the quantitative easing policy, central banks create provisions by buying bonds or other financial assets by reversing their assets. In turn, for the concept of "helicopter money", central banks distribute money without increasing the assets on their balance sheets. Economists also say that the impact of both concepts on the inflation expectations of market participants is different. Namely, "helicopter money" leading to an increase in money supply is perceived as more durable, i.e. more irreversible, than in the case of quantitative easing policy. Economists also believe that the final effect of both policies is not radically different from the effect of a combination of expansionary fiscal policy and expansionary monetary policy simultaneously.

Therefore, the appropriate monetary policy during a liquidity trap should not rely on further increasing the money supply, or on lowering the interest rate, but on raising inflation expectations by raising the nominal interest rate. In this situation, if the money supply drops, the nominal interest rate increases and investors are more likely to convert cash into interest-bearing assets. If the demand for money drops more than proportionally to the drop in the money supply due to pressure on interest rates, then inflation will increase. In other words, only when financial assets become more attractive than cash will the overall price level in the country increase. Of course, this type of liquidity trap only occurs when the economy is in a deep recession. If the economy is not in recession, monetary injections from the central bank should lead to higher inflation, as the low interest rate reduces the propensity to save, increasing the propensity for consumption and investment. However, expansionary monetary policy is necessary in particular when the economy is in a recession. ${ }^{16}$

An alternative way to get out of the liquidity trap is to conduct an expansionary fiscal policy as suggested by Keynes. However, in conditions of a high level of public debt, in particular in highly developed countries, fiscal expansion may be significantly limited. ${ }^{17}$

An analysis of past attempts to overcome deflation and the liquidity trap, and especially Japan's failed experiences in the 1990s and beyond, indicates that the overriding condition for effective monetary policy is effective and sustained stimulation of inflation expectations. These actions must be credible in the perception of market participants. Determining the inflation path in the form of a sufficiently wide range allows, in the long run, to consolidate the real interest rate at a negative or sufficiently

${ }^{15}$ D. K. Rosati: New trends in monetary policy after the financial crisis 2008-2012. Finance, Financial Markets, Insurance, No. 4/2016, p. 461-490.

${ }^{16}$ M. Krawczyk: On fiscal and monetary policy in the conditions of the liquidity trap, Economist, No. 4/2013, p. $475-496$.

${ }^{17}$ A. Szymańska: Effects of fiscal policy at low interest rates - a review of the literature, Studies in Law and Economics, Volume XCIII/2014, p. 331-349. 
low, positive level to encourage market participants to increase consumption and investment. $^{18}$

According to Svensson's proposal, an adequate depreciation of the national currency can be an effective method of raising inflation. In addition to the desired but controlled increase in inflation, this method ensures an increase in the country's foreign exchange reserves and reduces the susceptibility to a possible return of another crisis. Getting out of the debt trap by increasing inflation in the economy finds important theoretical justification in the form of conclusions from the analysis of the simplified Krugman economy model. The theoretical conclusion that deflation requires inflation creates the basis for practical actions in the field of unconventional monetary moves. The application of the quantitative easing method leads to increased liquidity in the financial system. ${ }^{19}$

The value of money is different in the inflation economy and in deflationary conditions. The creation of fiat money, undertaken to stimulate the economy, reduces the value of earlier savings to the level resulting from the inclusion of new money in circulation. The increase in debt due to the use of stimulus programs, leading to a higher budget deficit, and also to higher future inflation, means a partial appropriation of measures by business entities and households with real savings. It is obvious that although the issuing of additional money is a necessary procedure to get out of the liquidity trap, many proposed solutions and stimulus programs ultimately favor the wasteful storage of public money, allow the conversion of private debt to public debt, cause a decrease in budgetary discipline and create moral hazard. The weakness of the proposed remedies in the field of fiscal policy is the issue of efficiency of infrastructure expenditure. ${ }^{20}$

\section{Conclusions}

The last decade of low, nominal interest rates and relatively low inflation creates new challenges for monetary and fiscal policy. The current policy framework was primarily developed at a time when the nominal lower interest rate limit was not a major problem for central banks, and discretionary fiscal policy was not widely regarded as an important part of stabilization policies. ${ }^{21}$

The condition for an effective exit strategy from the liquidity trap is to skillfully combine structural reforms, fiscal policy and monetary policy. Pointing to the need for preventive measures, according to the principle that "one ounce of prevention is worth a pound of treatment", one should return to structural adjustments, i.e. healing the banking system, raising the state of financial supervision regulation and adaptation of necessary changes in the architecture of the global financial system. ${ }^{22}$

\footnotetext{
${ }^{18}$ M. Krawczyk: On fiscal and monetary policy in the conditions of the liquidity trap, Economist, No. 4/2013, p. 475-496.

${ }^{19}$ L. O. Svensson: The Zero Bound in an Open Economy: A Foolproof Way of Escaping from a Liquidity Trap, Monetary and Economic Studies, No 19/2001, p. 277-312.

${ }^{20}$ N. Roubini, S. Mihm: Economics of the crisis, Wolters Kluwer, Warsaw 2011, p. 1-371.

${ }^{21}$ T. Nakata, S. Schmidt: Expectations-driven liquidity traps: implications for monetary and fiscal Policy, ECB Working Paper Series, No 2304/2019, p. 1-54.

${ }^{22}$ E. Frejtag-Mika: The dispute about ways out of the trap of liquidity and deflation, Acta Universitatis Lodziensis Folia Oeconomica, No 3 (303)/2014, p. 91-107.
} 


\section{Literature}

Arias M. A., Wen Y.: The Liquidity Trap: An Alternative Explanation for Today's Low Inflation, The Regional Economist , 2014, April, https://www.stlouisfed.org/

Blanchard O., Cerutti E., Summers L.: Inflation and Activity - Two Explorations and their Monetary Policy Implications, IMF Working Paper, No 15/2015.

Frejtag-Mika E.: The dispute about ways out of the trap of liquidity and deflation. Acta Universitatis Lodziensis Folia Oeconomica, No 3 (303)/2014.

Friedman M.: The Role of Monetary Policy. American Economic Review, No 58 (1)/1968.

Hicks, J. R.: Mr. Keynes and the 'Classics', Econometrica, No 5 (2)/1937.

Keynes, J. M.: The General Theory of Employment, Interest, and Money, Macmillan, London 1936.

Krawczyk M.:. On fiscal and monetary policy in the conditions of the liquidity trap, Economist, No. 4/2013.

Krugman P. R.: It's Baaack: Japan's Slump and the Return of the Liquidity Trap, Brookings Papers on Economic Activity, No 29 (2)/1998.

Moe T. G., Marriner S.: Eccles and the 1951 Treasury - Federal Reserve Accord: Lessons for Central Bank Independence, Levy Economics Institute of Bard College Working Paper, No. 747/2013.

Nakata T., Schmidt S.: Expectations-driven liquidity traps: implications for monetary and fiscal Policy, ECB Working Paper Series, No 2304/2019. DOI: 10.17016 / FEDS. 2019.053

Orphanides, A.: The Fiscal-Monetary Policy Mix in the Euro Area - Challenges at the Zero Lower Bound. European Commission Discussion Paper No 060 , July 2017, 144. https://dx.doi.org/10.2139/ssrn.2965805

"Money dropped from a helicopter" as an option of monetary policy, https://www. Obserwator finansowy.pl (14.10.2019).

Rosati DK (2016). New trends in monetary policy after the financial crisis 2008-2012, Finance, Financial Markets, Insurance, No. 4/2017. DOI: 10.18276 / frfu.2016.4.82 / 1-39.

Roubini N., Mihm S.: Economics of the crisis , Wolters Kluwer, Warsaw 2011.

Price stability - why is it also important for you? https://www.ecb.europa.eu/pub/pdf/other/whypricestability_en.pdf (30/04/2019).

Svensson L.O.: The Zero Bound in an Open Economy: A Foolproof Way of Escaping from a Liquidity Trap, Monetary and Economic Studies, No 19/2001.

Szymańska A.: Effects of fiscal policy at low interest rates - a review of the literature, Studies in Law and Economics, Volume XCIII/2014.

Thirion G.: European Fiscal Union: Economic Rationale and Design Challenges, CEPS Working Document, No 01/2017.

Tobin J.: Keynesian Models of Recession and Depression, American Economic Review Papers and Proceedings, No 65/1975.

Vandenbroucke F., Luigjes C., Wood D., Lievens K.: Institutional Moral Hazard in the MultiTiered Regulation of Unemployment and Social Assistance Benefits and Activation - A Summary of Eight Country Case Studies, CEPS Special Report, No. 137/2016. 


\section{Pułapka płynności w USA, strefie euro i Japonii}

\section{Streszczenie}

Kiedy kraj wpada w pułapkę płynności, oznacza to, że jego bankowi centralnemu brakuje skutecznej, ekspansywnej polityki monetarnej mającej na celu zwiększenie popytu konsumpcyjnego i inwestycyjnego. Uczestnicy rynku (gospodarstwa domowe i przedsiębiorstwa) zamiast zwiększać popyt gromadzą rosnącą podaż pieniądza w postaci gotówki. Keynes argumentował, że dla gospodarki znajdującej się w pułapce płynności jedynym sposobem na zwiększenie popytu w kraju i pobudzenie gospodarki jest prowadzenie ekspansywnej polityki fiskalnej poprzez zwiększanie wydatków rządowych lub obniżanie podatków.

Celem badań jest weryfikacja empirycznej hipotezy o pułapce płynności w trzech największych gospodarkach świata, znanych wcześniej jako Globalna Triada (tj. USA, strefa euro i Japonia), po kryzysie finansowym w 2008 roku. W pracy wykorzystano metody badawcze oparte na studiach literaturowych z zakresu makroekonomii i finansów oraz metody statystyczne. Wszystkie dane statystyczne pochodziły z urzędu statystycznego Unii Europejskiej - EUROSTAT oraz z bazy danych statystycznych Konferencji Narodów Zjednoczonych ds. Handlu i Rozwoju UNCTADstat.

Słowa kluczowe: pułapka płynności, kryzys finansowy, polityka pieniężna JEL Codes: E52, E62, P24

Information about the author:

\section{Piotr Misztal}

Jan Kochanowski University in Kielce

Faculty of Law and Social Sciences

University-Street 15

25-406 Kielce

email: pmisztal@ujk.edu.pl

ORCID: 0000-0003-2609-3439 